\title{
Effect of Raffinose and Ultrasound Pulses on Invertase Release by Free and Immobilized Saccharomyces cerevisiae in Loofa (Luffa cylindrica) Sponge
}

\author{
Leila Larisa Medeiros Marques, João Batista Buzato* and Maria Antonia Pedrine \\ Colabone Celligoi \\ Departamento de Bioquímica e Biotecnologia; CCE; Universidade Estadual de Londrina; C. P. 6001; \\ buzato@uel.br; 86.051-990; Londrina - Paraná - Brasil
}

\begin{abstract}
This study investigated the effect of raffinose and ultrasound pulses on invertase release from free $\underline{S}$. cerevisiae and

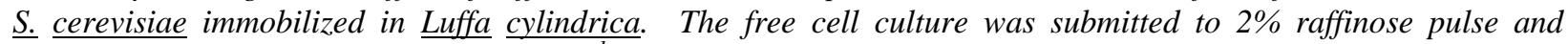
irradiated for 2 minutes at 0.12 and $0.46 \mathrm{~h}^{-1}$ dilution rates. The immobilized cell culture was submitted to raffinose pulse and irradiated for 1,2 and 4 minutes, at $0.10 \mathrm{~h}^{-1}$ dilution rate. In immobilized cells, the raffinose pulse increased the invertase activity from 5.38 to $7.27 \mathrm{U} / \mathrm{mg}$. Ultrasound application in free cell culture at the $0.12 \mathrm{~h}^{-1}$ dilution rate gave the best results. The activity varied from 25.08 to $29.38 \mathrm{U} / \mathrm{mg}$ while the increase in immobilized cells was from 5.22 to $9.70 \mathrm{U} / \mathrm{mg}$ when sonicated for two minutes. These results showed that ultrasound application in continuous culture could have great potential for application in biotechnological techniques.
\end{abstract}

Key words: Immobilization, invertase, Luffa cylindrica, raffinose, Saccharomyces cerevisiae, ultrasound

\section{INTRODUCTION}

Yeast invertase ( $\beta$-D-fructofuranoside fructohydrolase, E.C. 3.2.1.26) that catalyses the sucrose hydrolysis reaction has industrial interest for use to produce syrup from sucrose and molasses which has importance in the food industry. More recently this enzyme has been used as a sensor for continuous sucrose determination (Balasundaram and Pandit, 2001). Different methodologies have been proposed to increase enzyme release in the culture medium. The use of enzymatic inducers such as raffinose has given positive results in invertase release (Parascandola et al., 1993; Özcan et al., 1997; Brandão et al., 2002). Ultrasound has been used to extract and release intracellular enzymes such as invertase from $S$. cerevisiae (Balasundaram and Pandit, 2001), Phaffia rhodozyma (Persike et al., 2002), Aspergillus niger (Vargas et al., 2004) and acid phosphatase and ATPase from $S$. cerevisiae (Bucalon and Palma, 1990) and $\beta$-galactosidase from Lactobacillus (Wang and Sakakibara, 1997). In microbial cell cultures, high intensity ultrasound application ruptured cell walls, but low intensity ultrasound increased growth, promoted enzyme release, enhanced productivity in biological processes and, thus, could be a tool for improving biotechnological processes (Matsuura et al., 1994; Chisty, 2003).

Cell immobilization has some advantages when compared with free cell culture. The reaction

\footnotetext{
${ }^{*}$ Author for correspondence
} 
speed can be accelerated and a high dilution rate can be used in continuous fermentation without causing cell washing and it is less susceptible to the effect of inhibitory compounds and nutrient depletion (Lima et al., 2001). Many immobilization techniques for $S$. cerevisiae have been explored in several fermentation processes (Nigam, 2000; Navratil et al., 2001; Farid et al., 2002; Cibis et al., 2002; Rossi and Rocha, 2003; Yuengang et al., 2003). However, these methods frequently present limitations in stability, mass transfer inside the support and difficulty in their large scale preparation. They also require complex and sophisticated equipment that would increase production costs. Immobilization in lignocellulosic materials such as sugar cane bagasse, wood shavings, rice husks and straw also presents restrictions (Ogbonna et al., 1997). However, the loofa (L. cylindrica) sponge is an excellent support for cell immobilization because it is cheap, highly porous and resistant to autoclaving, $\mathrm{pH}$ variation and temperature, and is an ideal material for use in developing countries (Ogbonna et al., 1994; Roble et al., 2003). This study investigated the effect of raffinose and ultrasound pulses on invertase release from $S$. cerevisiae cells in continuous culture, both free and immobilized in L. cylindrica.

\section{MATERIAL AND METHODS}

\section{Microorganism and culture medium}

The industrial ethanol forming yeast $S$. cerevisiae used in this study was donated by the COROL Sugar and Alcohol Refinery (Cooperativa Agropecuária Rolândia Ltda-PR) Industry. It was maintained in solid medium containing $\left(\mathrm{gL}^{-1}\right)$ sucrose, 50; yeast extract, 4; peptone, $4 ; \mathrm{KH}_{2} \mathrm{PO}_{4}$, $1 ; \mathrm{MgSO}_{4} \cdot 7 \mathrm{H}_{2} \mathrm{O}, 0.1 ; \mathrm{CaCl}_{2} .2 \mathrm{H}_{2} \mathrm{O}, 0.1 ;\left(\mathrm{NH}_{4}\right)_{2} \mathrm{SO}_{4}$ and 1.5; agar, 15. The composition of the fermentation liquid medium was the same, but without the agar. The $\mathrm{pH}$ of the medium was adjusted to 5.5 and autoclaved at $121^{\circ} \mathrm{C}$ for 20 minutes before use.

\section{Experimental apparatus}

Continuous fermentation was carried out in a bioreactor with $1.2 \mathrm{~L}$ capacity and $0.6 \mathrm{~L}$ working volume, with fixtures for ultrasound probe entry, feed and heating. The culture was fed continually with fresh culture medium stored in a $20 \mathrm{~L}$ reservoir. An Ultrasonic Processor 20 kHz, model
GE 130 PB/70 W, from Sonics and Materials, was used equipped with a probe-type $9.5 \mathrm{~mm}$ diameter, continuous mode wave guide.

\section{Immobilization}

Loofa ( $L$. cylindrica) sponge was used as the support to immobilize $S$. cerevisiae cells. For use as support, the loofa sponge was cut into $4 \mathrm{~cm} \mathrm{x}$ $4 \mathrm{~cm}$ pieces and placed in the bioreactor containing culture medium. The system was then autoclaved.

\section{Culture conditions and pulses}

After adding 10\% (v/v) inoculum in the bioreactor, before starting continuous feeding, a batch fermentation was conducted for $5 \mathrm{~h}$ under gentle agitation at $30^{\circ} \mathrm{C} \pm 1$. The fermentation was performed at the following dilution rates: 0.12 ; $0.21 ; 0.33 ; 0.46 \mathrm{~h}^{-1}$ for free cells and $0.10 ; 0.14$; $0.29 ; 0.46 \mathrm{~h}^{-1}$ for immobilized cells. The raffinose and ultrasound pulses were applied to the culture during the steady state of continuous fermentation. The raffinose pulse was carried by the addition of $20 \mathrm{~mL}$ of $2 \%(\mathrm{w} / \mathrm{v})$ raffinose solution at the 0.12 and $0.46 \mathrm{~h}^{-1}$ dilution rates and at the $0.10 \mathrm{~h}^{-}$ ${ }^{1}$ dilution rate in the immobilized culture.

In the ultrasound pulse, the probe was immersed $2.5 \mathrm{~cm}$ in the culture. The culture was irradiated at a frequency of $20 \mathrm{kHz}$ and amplitude 20 . In free cells, the culture was sonicated for two minutes at a power input of $25 \mathrm{~W}$, at the 0.12 and $0.46 \mathrm{~h}^{-1}$ dilution rates, while in the immobilized cells, at times of 1, 2 and 4 minutes, at a power input of 33 $\mathrm{W}$ at $0.10 \mathrm{~h}^{-1}$ dilution rate.

\section{Assays}

The samples removed from the fermented syrup were centrifuged at $5583 \mathrm{~g}$ for 10 minutes and the supernatant used in the determinations. The invertase activity was determined by incubation at $37^{\circ} \mathrm{C}$ of a mixture of $1 \mathrm{~mL}$ sucrose solution $0.3 \mathrm{M}$, $3 \mathrm{~mL}$ acetate buffer, $\mathrm{pH} 4.7$ and $1 \mathrm{~mL}$ culture supernatant that contained invertase. The samples were collected after 20 minutes and the reducing sugars released were determined using the dinitrosalicylic acid method (Miller, 1959). One unit of enzymatic activity was defined as the amount of enzyme releasing $1 \mu \mathrm{mol}$ of reducing sugar per minute in assay conditions. The specific activity was expressed in enzymatic activity units per mg extracellular protein. The protein concentration was determined by the Hartree method (1972) using bovine albumin as standard. Sucrose hydrolysis was estimated by the 
difference between total sugar (Duboi et al., 1956) and reducing sugar.

\section{Viability test}

The culture viability was assessed microscopically with the aid of methylene blue (Thomas and Ingledew, 1990) and cell counting in Neubauer chamber.

\section{RESULTS AND DISCUSSION}

\section{Immobilization}

S. cerevisiae cell immobilization in cellulose-rich materials has been little studied. Lamptey and Moo-Young (1987) used wood shavings and obtained values of 66.7 and $188.0 \mathrm{mg}$ cells/ $\mathrm{g}$ support. Michaux et al. (1982) used sawdust added to gelatin and obtained immobilization values ranging from 94.2 to $145 \mathrm{mg}$ cells/ g support. More recently, loofa sponge has been used as support for immobilization. Iqbal and Zafer (1994) were pioneers in fungus, yeast and bacteria immobilization in Luffa cylindrica. Ogbonna et al. (1994) obtained a value of $4.4 \mathrm{~g} S$. cerevisiae cells /g of loofa sponge. Roble et al. (2003) assessed various cell immobilization methods in this support. The best result was $4.65 \mathrm{~g}$ $S$. cerevisiae/ g support. In the present study, at a dilution rate of $0,10 \mathrm{~h}^{-1}$, a high concentration of immobilized cells was ascertained: $5.5 \mathrm{~g}$ cells per gram of support. This result showed loofa sponge as an excellent support for $S$. cerevisiae immobilization.

\section{Invertase production}

Table 1 shows invertase production and sucrose hydrolysis in continuous fermentation by free $S$. cerevisiae cells and $S$. cerevisiae cells immobilized in loofa sponge.

Table 1 - Invertase production and sucrose hydrolysis, in continuous Saccharomyces cerevisiae cell culture, at different dilution rates.

\begin{tabular}{cccccc}
\hline \multicolumn{1}{c}{ Free cells } & \multicolumn{2}{c}{ Immobilized cells } \\
\hline $\begin{array}{c}\text { Dilution rate } \\
\left(\mathbf{h}^{-\mathbf{1}}\right)\end{array}$ & $\begin{array}{c}\text { Specific Activity } \\
\text { (U/mg prot) }\end{array}$ & $\begin{array}{c}\text { Sucrose } \\
\text { hydrolysis } \\
(\boldsymbol{\%})\end{array}$ & $\begin{array}{c}\text { Dilution rate } \\
\left(\mathbf{h}^{-\mathbf{1}}\right)\end{array}$ & $\begin{array}{c}\text { Specific Activity } \\
(\mathbf{U} / \mathbf{m g} \text { prot })\end{array}$ & $\begin{array}{c}\text { Sucrose } \\
\text { hydrolysis } \\
(\boldsymbol{\%})\end{array}$ \\
\hline $\mathbf{0 . 1 2}$ & 23.69 & 98 & $\mathbf{0 . 1 0}$ & 5.38 & 99 \\
$\mathbf{0 . 2 1}$ & 5.04 & 97 & $\mathbf{0 . 1 4}$ & 1.88 & 99 \\
$\mathbf{0 . 3 3}$ & 0.22 & 43 & $\mathbf{0 . 2 9}$ & 0.87 & 58 \\
$\mathbf{0 . 4 6}$ & 0.20 & 19 & $\mathbf{0 . 4 6}$ & 0.41 & 30 \\
\hline
\end{tabular}

The highest values of enzymatic activity were detected at low dilution rates, in both free and immobilized cells; however, the enzymatic activity values ranged greatly. At the two lower dilution rates studied, the enzyme activity in free cell culture were higher compared to the immobilized cell cultivation. Pyn et al. (1999) studied the invertase expression in continuous culture by free $S$. cerevisiae containing the SUC2 gene cloned on a multicopy plasmid. Invertase activity measurements were based on the method involving whole cells and the highest value achieved was 259U/mg cells. Results obtained for free cells showed similar pattern with those of Kushi et al. (2000) who reported a decrease activity of inulinase with increasing dilution rates and high residual sugar concentrations were found. The presence of high residual sugar quantities led to lower enzyme activity which indicated a relation between enzyme activity and residual sugar. Invertase activity in continuous culture of $S$. cerevisiae cells immobilized in gelatin was assessed by Parascandola et al. (1993). These authors found extracellular enzymatic activity values higher than in the present study as a value of $12 \mathrm{U} / \mathrm{mg}$ was achieved. In present study, the low enzymatic activity values found in immobilized cells were probably because of the large quantity of biomass immobilized in the support due to the excellent property of the loofa sponge as support for immobilization and the strain used presents great readiness for flocculation. Consequently, stratified layers of cells formed that probably hindered the release of invertase from the interior of the immobilized biomass.

This study also assessed the hydrolysis of the sucrose present in the culture medium. The 
hydrolysis was practically total, over $97 \%$ at low dilution rates in both free and immobilized cells. However, the hydrolysis values obtained were not satisfactory at the two higher dilution rates tested. Chang et al. (1996) assessed sucrose hydrolysis in continuous culture of $S$. cerevisiae cells immobilized in alginate capsules. The host strain used was S. cerevisiae SEY 2102 containing plasmid pRB58 with the SUC2 gene encoding invertase. Sucrose hydrolysis was maintained at $95 \%$ at dilution rates of 0.1 to $0.6 \mathrm{~h}^{-1}$.

\section{Raffinose pulse}

Table 2 shows the results of raffinose pulse in free cells. The raffinose pulse was conducted at dilution rates of 0.12 and $0.46 \mathrm{~h}-1$.

Table 2 - Effects of ultrasound and raffinose pulses on invertase activity in continuous culture with free Saccharomyces cerevisiae cells.

\begin{tabular}{cccccc}
\hline & & \multicolumn{2}{c}{ Ultrasound pulse } & \multicolumn{2}{c}{ Raffinose pulse } \\
\cline { 3 - 6 } & $\begin{array}{c}\text { Dilution rate } \\
\left(\mathbf{h}^{-1}\right)\end{array}$ & $\begin{array}{c}\text { Invertase Activity } \\
(\mathbf{U} / \mathbf{m L})\end{array}$ & $\begin{array}{c}\text { Specific Activity } \\
(\mathbf{U} / \mathbf{m g})\end{array}$ & $\begin{array}{c}\text { Invertase Activity } \\
(\mathbf{U} / \mathbf{m L})\end{array}$ & $\begin{array}{c}\text { Specific Activity } \\
(\mathbf{U} / \mathbf{m g})\end{array}$ \\
\hline $\begin{array}{c}\text { Steady state } \\
\text { Greatest value after } \\
\text { pulse }\end{array}$ & 0.12 & 60.69 & 25.08 & 60.11 & 23.69 \\
$\begin{array}{c}\text { Steady state } \\
\text { Greatest value after } \\
\text { pulse }\end{array}$ & 0.12 & 70.97 & 29.38 & 64.62 & 23.73 \\
\hline
\end{tabular}

The results presented little variation in the enzymatic activity. At a dilution rate of $0.12 \mathrm{~h}^{-1}$ it was $23.72 \mathrm{Umg}^{-1}$ while at a dilution rate of $0.46 \mathrm{~h}^{-1}$ it was less than $0.3 \mathrm{Umg}^{-1}$. Parascandola et al. (1993) investigated the effect of raffinose as carbon source in invertase production in large scale culture of free $S$. cerevisiae cells, and obtained an increase from 7 to $13 \mathrm{Umg}^{-1}$ in specific invertase activity during the exponential phase. Brandão et al. (2002) investigated invertase activity under repressive and non-repressive growth conditions. For this, the $S$. cerevisiae cells were grown on different carbon sources: glucose, fructose, galactose and raffinose. The highest invertase activity value was obtained when raffinose was used as carbon source. The effect of raffinose pulse on immobilized cells is shown in Table 3. Due to the low activity values obtained with free cells, at the $0.46 \mathrm{~h}^{-1}$ dilution rate, the raffinose pulse in the immobilized cells was conducted in $0.10 \mathrm{~h}^{-1}$ dilution rate. The values obtained, after applying the pulse, were 20.02 $\mathrm{UmL}^{-1}$ and 7.27 $\mathrm{Umg}^{-1}$. Parascondola et al. (1993) cultivated immobilized $S$. cerevisiae cells on a large scale using raffinose for invertase production. These authors obtained an increase in specific invertase activity from 8 to $18 \mathrm{Umg}^{-1}$.

\section{Ultrasound pulse}

The effect of the ultrasound pulse on free cells is shown in Table 2. The ultrasound pulse was conducted at 0.12 and $0.46 \mathrm{~h}^{-1}$ dilution rates. At $0.12 \mathrm{~h}^{-1}$ dilution rate, the activity increased $17 \%$ (Fig. 1).

The values obtained after applying the pulse were $70.97 \mathrm{UmL}^{-1}$ and $29.38 \mathrm{Umg}^{-1}$. At the $0.46 \mathrm{~h}^{-1}$ dilution rate, the results varied but presented low magnitude (Fig. 2).

Bucalon and Palma (1990) investigated the effect of sonication on the start of a batch $S$. cerevisiae culture. Cell radiation with frequency of $1.8 \mathrm{mHz}$ and intensity of $200 \mathrm{mWcm}^{-2}$ caused a slight increase in the phosphatase and ATPase activity. However, there was a large increase when the frequency of $20 \mathrm{kHz}$ and intensity of $10 \mathrm{Wcm}^{-2}$ were applied. Lanchun et al. (2003) observed that ultrasound application on a Saccharomyces cerevisiae batch culture at frequency of $24 \mathrm{kHz}$ and power input of $2 \mathrm{~W}$ raised the proteinase activity values by $24 \%$. Vargas et al. (2003) assessed the ultrasound application time on invertase release in batch $S$. cerevisiae culture. The greatest enzymatic activity detected without causing cell rupture was $1.08 \mathrm{UmL}^{-1}$, using frequency of $20 \mathrm{kHz}$, amplitude 40 , intensity of $0.62 \mathrm{WmL}^{-1}$ ultrasound radiations and up to five 
minutes sonication.

The effect of ultrasound on $S$. cerevisiae cells immobilized in loofa sponge is shown in Table 3. Due to the low activity values obtained with free cells at the $0.46 \mathrm{~h}^{-1}$ dilution rate, the ultrasound pulse on the immobilized cells was conducted at $0.10 \mathrm{~h}^{-1}$ dilution rate. The sonication times used were 1,2 and 4 minutes. At the one minute time, the activity values were $22.20 \mathrm{UmL}^{-1}$ and 8.09 $\mathrm{Umg}^{-1}$, respectively, after pulse application. At the two minute time, the values obtained were 31.21 $\mathrm{Umg}^{-1}$ and $9.70 \mathrm{Umg}^{-1}$, after five minutes ultrasound application (Fig. 3).

These values represented an increase of 100 and
$86 \%$, respectively. At the 4 minutes sonication time, the values obtained were $18.88 \mathrm{Uml}^{-1}$ and $7.32 \mathrm{Umg}^{-1}$. Therefore, the best ultrasound application time in immobilized cells was 2 minutes.

The cell viability was assessed at 5, 15, 55, 90 and 120 minutes, after applying ultrasound to the cells. The viability rate was over $95 \%$ at the sonication times of 1 and 2 minutes. However, in the 4 minute application, a mortality rate of up to $46 \%$ was ascertained (data not shown). The ultrasound pulse, at low frequency and for a short period increased cell permeability, consequently compound release was high.

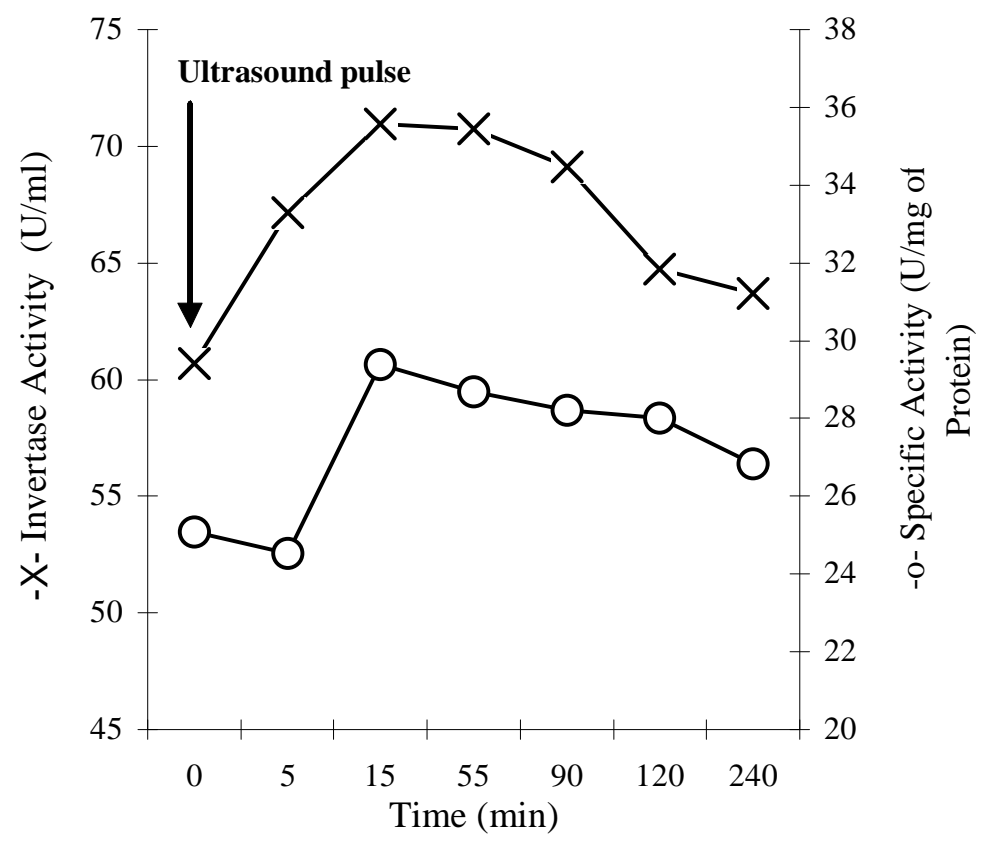

Figure 1 - Effect of ultrasound pulse on invertase activity, of free Saccharomyces cerevisiae cells at $0.12 \mathrm{~h}^{-1}$ dilution rate

Table 3 - Effect of ultrasound and raffinose pulsing times on the invertase activity of immobilized Saccharomyces cerevisiae at $0.10 \mathrm{~h}^{-1}$ dilution rate.

\begin{tabular}{cccccccccc}
\hline & \multicolumn{1}{c}{ Ultrasound pulse 1' } & \multicolumn{2}{c}{ Ultrasound pulse 2' } & \multicolumn{2}{c}{ Ultrasound pulse 4' } & \multicolumn{2}{c}{ Raffinose pulse } \\
\cline { 2 - 9 } & $\begin{array}{c}\text { Invertase } \\
\text { Activity } \\
(\mathbf{U} / \mathbf{m L})\end{array}$ & $\begin{array}{c}\text { Specific } \\
\text { Activity } \\
(\mathbf{U} / \mathbf{m g})\end{array}$ & $\begin{array}{c}\text { Invertase } \\
\text { Activity } \\
(\mathbf{U} / \mathbf{m L})\end{array}$ & $\begin{array}{c}\text { Specific } \\
\text { Activity } \\
(\mathbf{U} / \mathbf{m g})\end{array}$ & $\begin{array}{c}\text { Invertase } \\
\text { Activity } \\
(\mathbf{U} / \mathbf{m L})\end{array}$ & $\begin{array}{c}\text { Specific } \\
\text { Activity } \\
(\mathbf{U} / \mathbf{m g})\end{array}$ & $\begin{array}{c}\text { Invertase } \\
\text { Activity } \\
(\mathbf{U} / \mathbf{m L})\end{array}$ & $\begin{array}{c}\text { Specific } \\
\text { Activity } \\
(\mathbf{U} / \mathbf{m g})\end{array}$ \\
\hline $\begin{array}{c}\text { Steady state } \\
\text { Greatest value } \\
\text { after pulse }\end{array}$ & 15.64 & 5.23 & 15.58 & 5.22 & 15.54 & 5.22 & 15.86 & 5.38 \\
\hline
\end{tabular}




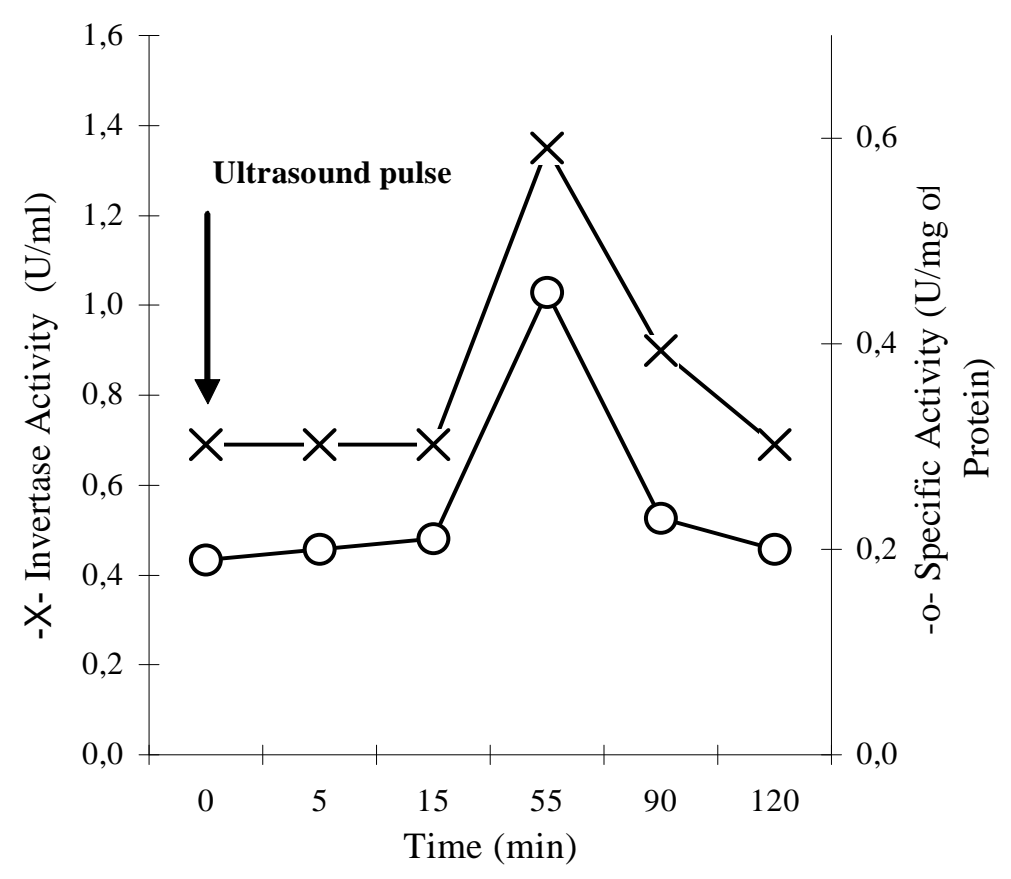

Figure 2 - Effect of ultrasound pulse on invertase activity on free Saccharomyces cerevisiae cells at $0.46 \mathrm{~h}^{-1}$ dilution rate.

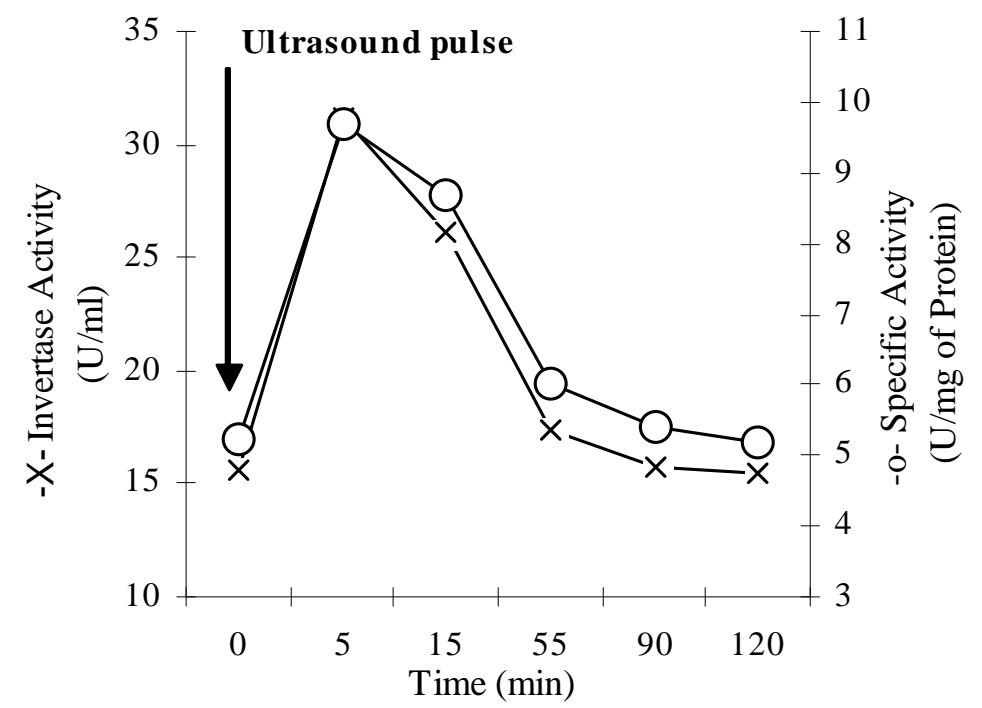

Figure 3 - Effect of 2 minute ultrasound pulse on invertase activity in immobilized Saccharomyces cerevisiae cells at $0.10 \mathrm{~h}^{-1}$ dilution rate. 
In this study, an increase was obtained in protein release that was mostly invertase, shown by the increase in the specific activity.

The present study confirmed loofa sponge as an excellent support for $S$. cerevisiae immobilization due to the high values of biomass aggregated to it but it hindered invertase release. Consequently, the invertase activity values were low in immobilized cells, at low dilution rates, when compared to the values obtained in free cells. Therefore, the immobilization of $S$. cerevisiae cells in Luffa cylindrica was shown not to be a suitable method for invertase production. The values obtained with the raffinose pulse were lower than those with ultrasound, both in free cell culture and in immobilized cell culture. In this study, the use of ultrasound pulse increased invertase release, and therefore, its application could be promising in improving biotechnological processes.

\section{ACKNOWLEDGEMENTS}

Marques, L. L. M. is grateful to CAPES for financial support.

\section{RESUMO}

Neste trabalho investigou-se o efeito de pulsos de rafinose e ultra-som, na liberação de invertase de Saccharomyces cerevisiae livre e imobilizado em Luffa cylindrica. A cultura de células livres foi submetida a pulso de rafinose $2 \%$ e irradiada por 2 min, nas taxas de diluição 0,12 e $0,46 \mathrm{~h}^{-1}$. A cultura de células imobilizadas foi submetida a pulso de rafinose e irradiada por 1, 2 e $4 \mathrm{~min}$, em taxa de diluição $0,10 \mathrm{~h}^{-1}$. Em células imobilizadas, o pulso de rafinose aumentou a atividade invertásica de 5,38 para 7,27 U/mg. Entretanto a aplicação do ultra-som, em cultivo de células livres na taxa de diluição $0,12 \mathrm{~h}^{-1}$, obteve-se os melhores resultados. A atividade variou de 25,08 para $29,38 \mathrm{U} / \mathrm{mg}$, enquanto que o aumento em células imobilizadas foi de 5,22 para 9,70 U/mg, quando sonicadas por $2 \mathrm{~min}$. Esses resultados demonstram que a aplicação de ultra-som, em cultivo contínuo de células livres, pode ter um grande potencial de aplicação em processos biotecnológicos.

\section{REFERENCES}

Balasundaram, B. and Pandit, A. B. (2001), Selective release of invertase by hydrodynamic cavitation. Biochem. Eng. J., 8, 251-256.

Bucalon, A. J. and Palma, M. S. (1990), Bioeffects of ultrasound in yeast cells suspensions. Rev. Bras. Eng., 7, 265-272.

Brandão, R. L.; Etchebehere, L.; Queiroz, C. C.; Tropia, M. J.; Ernandes, J. R.; Gonçalves, T.; Dias, M. C. L.; Winderickx, J.; Thevelein, J. M.; Leiper, F. C.; Carling, D. and Castro, I. M. (2002), Evidence for involvement of Saccharomyces cerevisiae protein kinase $\mathrm{C}$ in glucose induction of HXT genes and derepression of SUC2. FEMS Yeast Res., 2, 93-102.

Chang, H. N.; Seong, G. H.; Yoo, I. K.; Park, J. K. and Seo, J. H. (1996), Microencapsulation of recombinant Saccharomyces cerevisiae cells with invertase activity in liquid-core alginate capsules. Biotechnol. Bioeng., 51, 157-162.

Chisti, Y. (2003), Sonobioreactors: using ultrasound for enhanced microbial productivity. Trends Biotechnol., 21, 89-93.

Cibis, E.; Zboromirska, W. B.; Garncarek, Z.; Gasperowicz, A. and Krzywonos, M. (2002), Kinetic analysis of Saccharomyces cerevisiae cell immobilization onto ceramic supports. Pol. J. Food Nutr. Sci., 11, 51-56.

Duboi, M.; Gilles, K. A. and Hamilton, J. K. (1956), Colorimeric methods for determination of sugar and related substances. Anal. Chem., 28, 350-356.

Farid, M. A.; El-Enshasy, H. A. and El-Deen, A. M. N. (2002), Alcohol production from starch by mixed cultures of Aspergillus awamori and immobilized Saccharomyces cerevisiae at different agitation speeds. J. Basic Microbiol., 42, 162-171.

Hartree, E. S. (1972), Determination of protein: a modification of Lowry method that gives a linear photometric response. Anal. Biochem., 48, 422-427.

Iqbal, M. and Zafar, S. I. (1994), Vegetable sponge as a matrix to immobilize micro-organisms: a trial study for hyphal fungi, yeast and bacteria. Lett. Appl. Microbiol., 18, 214-217.

Kushi, R. T.; Monti, R. and Contiero, J. (2000), Production, purification and characterization of na extracellular inulinase from Kluyveromyces marxianus var. bulgaricus. J. Ind. Microbiol. Biotechnol., 25, 63-69.

Lamptey, J. and Moo-Young, M. (1987), Immobilization of yeast cells by adsorption on wood chips. Methods Enzymol., 135, 333-340.

Lanchun, S., Bochu, W., Liancai, Z. Jie, L., Yanhong, Y. and Chuanren, D. (2003), The influence of lowintensity ultrasonic on some physiological characteristics of Saccharomyces cerevisiae. Colloids Surf. B, 30, 61-66. 
Lima, U. A.; Aquarone, E.; Borzani, W. and Shimidell, W. (2001), Reatores com células imobilizadas. In: Blücher, E. (Ed.). Biotecnologia Industrial. São Paulo. v. 2. pp. 355-371.

Matsuura, K.; Hirotsune, M.; Nunowawa, Y.; Satoh, M. and Honda, K. (1994), Acceleration of cell growth and ester formation by ultrasonic wave irradiation. $J$. Ferment. Bioeng., 77, 36-40.

Michaux, M.; Paquot, M.; Baijot, B. and Thonart, P. (1982), Continuous fermentation: improvement of cell immobilization by zeta potential measurement. Biotechnol. Bioeng. Symp.,12, 475-484.

Miller, G. H. (1959), Use of dinitrosalicylic acid reagent for determination of reducing sugar. Anal. Chem., 31, 426-429.

Navratil, M.; Sturdik, E. and Gemeiner, P. (2001), Batch and continuous mead production with pectate immobilised, ethanol-tolerant yeast. Biotechnol. Lett., 23, 977-982.

Nigam, J. N. (2000), Continuous ethanol production from pineapple cannery waste using immobilized yeast cells. J. Biotechnol., 80, 189-193.

Ogbonna, J. C.; Liu, Y. C.; Liu, Y. K. and Tanaka, H. (1994), Loofa (Luffa cylindrica) sponge as a carrier for microbial cell Immobilization. J. Ferment. Bioeng., 78, 437-442.

Ogbonna, J. C.; Tomiyama, S.; Liu, Y. C and Tanaka, H. (1997), Efficient production of ethanol by cells Immobilized in Loofa (Luffa cylindrica) sponge. $J$. Ferment. Bioeng., 84, 271-274.

Özcan, S.; Vallier, L. G.; Flick, J. S.; Carlson, M. and Johnston, M. (1997), Expression of the SUC2 gene of Saccharomyces cerevisiae is induced by low levels of glucose. Yeast, 13, 127-137.

Parascandola, P.; Alteriis, E. and Scardi, V. (1993), Invertase and acid phosphatase in free and gelimmobilized cells of Saccharomyces cerevisiae grown under different cultural conditions. Enzyme Microb. Technol., 15, 42-49.

Persike, D. S.; Bonfim, T. M. B.; Santos, M. H. R.; Lyng, S. M. O.; Chiarello, M. D. and Fontana, J. D. (2002), Invertase and urease activities in the carotenogenic yeast Xanthophyllomyces dendrorhous (formerly Phaffia rhodozyma). Bioresour. Technol., 82, 79-85.

Pyun, Y. R.; Jo, J. S.; Park, J. W. and Shin, H. H. (1999), Effects of oxygen on invertase expression in continuous culture of recombinant Saccharomyces cerevisiasecontaining the SUC2 gene. Appl. Microbiol. Biotechnol., 51, 334-339.

Roble, N. D.; Ogbonna, J. C. and Tanaka, H. (2003), A novel circulating loop bioreactor with cells immobilized in loofa (Luffa cylindrica) sponge for the bioconversion of raw starch to ethanol. Appl. Microbiol. Biotechnol., 60, 671-678.
Rossi, J. C. A. and Rocha, M. H. M. L (2003), A strategic study using mutant-strain entrapment in calcium alginate for the production of Saccharomyces cerevisiae cells with high invertase activity. Biotechnol. Appl. Biochem., 38, 43-51.

Thomas, K. C. and Ingledew, W. M. (1990), Fuel alcohol production: effects of free amino nitrogen on fermentation of very-high-gravity wheat mashes. Appl. Environ. Microbiol., 56, 2046-2050.

Vargas, L. H. M.; Campos, V. E. and Celligoi, M. A. P. C. (2003), Avaliação do tempo de sonicação na liberação de invertase por Saccharomyces cerevisiae. In: SINAFERM. CD-ROM. Florianópolis, Brazil.

Vargas, L. H. M.; Pião, A. C. S.; Domingos, R. N. and Carmona, E. C. (2004), Ultrasound effects on invertase from Aspergillus niger. World J. Microbiol. Biotechnol., 20, 137-142.

Yuegang, L.; Jiajin, M. and Tiancheng, G. (2003) The study on ethanol fermentation by immobilized inulinase and yeast cell using inulin as raw material. Food Ferment. Ind., 29, 66-68.

Wang, D. and Sakakibara, M. (1997), Lactose hydrolysis and $\beta$-galactosidase activity in sonicated fermentation with Lactobacillus strains. Ultrasonics Sonochem., 4, 255-261.
Received: April 19, 2005; Revised: January 25, 2006; Accepted: September 11, 2006. 